Georgia State University

ScholarWorks @ Georgia State University

\title{
Respectable Ladies and Uncouth Men: The Performative Politics of Class and Gender in the Public Realm of an Italian City
}

\author{
Emanuela Guano \\ Georgia State University, eguano@gsu.edu
}

Follow this and additional works at: https://scholarworks.gsu.edu/anthro_facpub

Part of the Anthropology Commons

\section{Recommended Citation}

Emanuela Guano. "Respectable Ladies and Uncouth Men: The Performative Politics of Class and Gender in the Public Realm of an Italian City." The Journal of American Folklore, vol. 120, no. 475, 2007.

https://doi.org/10.1353/jaf.2007.0011

This Article is brought to you for free and open access by the Department of Anthropology at ScholarWorks @ Georgia State University. It has been accepted for inclusion in Anthropology Faculty Publications by an authorized administrator of ScholarWorks @ Georgia State University. For more information, please contact scholarworks@gsu.edu. 


\section{Respectable Ladies and Uncouth Men: The Performative Politics of Class and Gender in the Public Realm of an Italian City}

According to the Webster's dictionary, being respectable means being "decent or correct in character or behavior" or being "fit to be seen." In this article, I approach "decent behavior" and "fitness to be seen" as the staple factor in the negotiation and the struggle over the place of women in the streets of an Italian city. Drawing on ethnographic research conducted in Genoa between 2002 and 2005, this article explores how middle-class women perform a classed and gendered respectability to resist their exclusion from an intensely masculinized public realm.

A "place of promenades, encounters, intrigues, diplomacy, trade and negotiations, theatricalizing itself" as well as a "vast setting where ... rituals, codes, and relations become visible and acted out": this is how Henri Lefebvre (1996:174) described the intense sociability of Mediterranean streets and plazas. In his explorations of an Italian city, Walter Benjamin, too, expressed surprise at how private life keeps bursting out of the domestic sphere to be negotiated publicly. In this environment, Benjamin argued, houses are "less the refuge into which people retreat than the inexhaustible reservoir from which they flood out" (1985:236-37). Indeed, Italian streets and piazzas are known for their brimming social life, the hustle and the bustle that animate them. At any time of the day, people from all walks of life can be seen engaging in a broad range of activities-from going to work to walking the dog, from windowshopping to getting groceries. Yet, upon closer examination, the apparent chaos of the Italian street turns out to have a certain orderliness: a logic that becomes perceptible once one starts paying closer attention to the social drama unfolding before one's eyes. ${ }^{1}$ In reporting on his experiences in the Italian street, Donald Pitkin observed that, "[i]n the ritual of the passeggiatta [sic] the ordinary citizen is making a [bella] figura, an impression, in a manner analogous to that once undertaken by the circulation of the well-born and nobility in the grand salon of patrician palaces. That aspect of personhood which figura refers to is an expression of the interaction between personal aspiration and assessment by others" (1993:98). ${ }^{2}$ Taking a closer ethnographic look at the passeggiata (ritual promenade) in Sasso, a small town in central Italy, Giovanna Del Negro (2004) more recently demonstrated how, through their 
conscious enactment of a gendered and classed social theater, middle-class Sassani negotiate their standing as modern and cosmopolitan members of the local society. The passeggiata in Sasso, however, is not exclusively an expressive activity. Rather, the practice of seeing and being seen in this town's piazza is also a venue for what Del Negro calls "bodily divination," the attempt to gain insights into the moral qualities of others by reading their looks and demeanor (2004:66).

Indeed, after walking in the streets of an Italian city, one invariably returns home with an updated and vividly visual picture of "society," as well as a few more ideas about one's place in it as a gendered and classed individual. As one of my research subjects put it, the street is the place where, by seeing people from all walks of life, "you relate yourself to the world" (ti relazioni al mondo). ${ }^{3}$ Most of the encounters that take place in the public realm of the Italian city are fleeting; yet, in each of them, even the briefest glimpse is enough to carry out competently the habitual task of assessing the other (while being assessed in return) on the basis of one's more or less adequate performance of gendered and classed respectability. ${ }^{4}$

While anyone walking in the streets of an Italian city is expected to meet minimal standards of decorum, women in particular are held accountable for a performance of respectability that requires a careful orchestration of looks and demeanor, visibility and modesty (Del Negro 2004). In past scholarship, women's performances of respectability in patriarchal societies have often been labeled as a form of sheer compliance. In his analysis of the politics of class, gender, and nation in the central European societies of the twentieth century, for example, George Mosse (1985:4-18) described respectability as a means through which Europe's rising middle classes sought to distinguish themselves from both the working class and the bourgeoisie. In this pursuit, morals and manners blended in the attempt to "assign everybody his or her place in life: men, children, and women" (1985:16), with women being especially in charge of embodying propriety. Due to its attention to the relevance of respectability in the construction of difference, Mosse's work made a significant contribution to understanding the complex relationship between class and gender identities. What Mosse overlooked, however, is the possibility that the very same discourse on respectability may entail a negotiation, and even a struggle, over who belongs where.

The importance of women in upholding respectability was also central to Peter Wilson's discussion of morals and manners on a small Caribbean island (1973). Respectability, Wilson suggested, is instrumental to the reproduction of a Europeaninspired class stratification with which, he surmised, women are only too happy to comply. Rather than concern themselves with the respectability of their wives' domestic sphere, the Caribbean men described by Wilson, instead, preferred to establish allegedly egalitarian relations of reputation in a public realm, pictured as a freer (and more genuinely Caribbean) arena for playful male prowess and rambunctiousness. Drawing on Wilson's work, Roger Abrahams (1983) reiterated the notion that, while male adeptness at verbal performance (be it "rude" or "sweet") is a form of cultural creativity, women's concern with respectability lacks any performative ingenuity, and is, in fact, just a mere repetition of static norms. It is as hard to agree with Wilson's and Abrahams's indictment of women's alleged conservatism as it is to accept their 
implicit praise for the masculinist ethos of reputation. Just as problematic is their insistence on the complete separation between the masculine public sphere of reputation and the feminine domestic realm of respectability, a simplification that has been frequently questioned by feminist scholars (Coole 2000; Gal 2002; Kerber 1988). Nonetheless, Wilson's and Abrahams's concern with the performative dimensions of respectability, its gendered practices, and its spatial arenas provides a useful springboard for conceptualizing the performative intricacies of gender.

A more nuanced approach to issues of gender and respectability is offered by feminist folklorists and anthropologists who tackle the forms of resistance-or, at least, moderate empowerment-embedded in women's performances of modesty and propriety. For example, in her explorations of Moroccan women's henna ceremonies, Deborah Kapchan (1993) showed how this form of decoration draws attention to women's bodies even as it hides them, thus simultaneously reinforcing and eroding dominant norms of female modesty. Writing about the modesty prescription fulfilled by the burqa (veil) used by Afghani women, Lila Abu-Lughod (2002) more recently argued that what in U.S. political rhetoric has become a symbol of Muslim women's oppression is, in fact, instrumental to granting ostensibly "respectable" women a degree of access to a public domain from which they would be otherwise completely excluded. What emerges from ethnographies such as Kapchan's and AbuLughod's is the tangle of consent and resistance, empowerment and repression, that unfolds from even the most impeccable performance of modest, respectable womanhood: even performative roles that are scripted along the lines of explicitly patriarchal norms may, after all, provide women with a venue for enacting agency.

In this article, I draw on ethnographic research conducted in Genoa, Italy, between 2002 and 2005 to explore the politics of gender, class, and respectability in a public realm that, due to its vibrancy and intensity, may well compare with the ones described by Wilson and Abrahams. ${ }^{5}$ Like them, I approach respectability as a set of discursive practices and prescriptions that the Genoese middle-class publics use to establish performatively not only who is to be seen where but also how one is to be seen. Drawing on feminist scholarship, I explore women's performance as a form of aesthetic creativity that, while negotiated within the confines of existing patriarchal norms, may grant women a degree of empowerment. More specifically, I argue that Genoa's middle-class women may use their mastery of the art of performing respectability for the sake of negotiating their place in a public realm that is largely marked as masculine. ${ }^{6}$

\section{Setting the Stage: Public Life in Genoa}

A city of approximately 630,000, Genoa is situated on the northern Tirrenian coast of Italy. ${ }^{7}$ Like most Italian cities, much of Genoa's public life is centered on a bustling downtown where the ground floors of elegant nineteenth-century apartment complexes host upscale businesses. ${ }^{8}$ Right next to this city's downtown-the product of a nineteenth-century modernization project-is the historic city center: a medieval labyrinth of dark, serpentine alleys and run-down patrician mansions that is currently undergoing a hefty renovation. On its north and west ends, Genoa's downtown 
borders on a ring of nineteenth-century middle-class neighborhoods that gradually fade into lower-middle- and working-class peripheries. In contrast, the East End (Levante) merges with the elegant Riviera. As it clings to the Apennines overlooking the Mediterranean, Genoa offers a variety of scenic promenades, terraces, and streets from which it is possible to capture breathtaking glimpses of the coastline and the mountains, as well as the architectural layers accumulated over more than two thousand years of history. Valorized through a process of urban renewal launched in the early 1990s as an alternative to the ailing industrial economy (Guano 2006), these opportunities for "natural" and "cultural" sightseeing provide a fit excuse (if one is ever needed) for the social exercise of the urban stroll, a practice that Genoa's increasingly white-collar and middle-class population (Arvati 1988) carries out with a keen pleasure.

During the warm season, the seaside promenades of Corso Italia and Nervi brim with smartly dressed crowds enjoying the view and the sea breeze as well as the sight of their fellow Genoese. In fall and winter, much of the passeggiata practice is performed downtown, especially in the very central Via Venti Settembre. The local slang for strolling in Via Venti is "fare le vasche" (literally, to "do laps": to walk back and forth from one end of the street to the other). Even though looking at other people is an important aspect of this practice, the windows of some of the city's most elegant stores provide additional entertainment to Genoese flâneurs and flâneuses, and so do the coffee shops that, in summer, set up their tables and chairs directly on the sidewalk, thus allowing for an uninterrupted socioscopic experience.

The downtown or riverside passeggiata is predominantly, though certainly not exclusively, a middle-class practice, though working-class Genoese from the periphery of the city might partake in it, too. However, the latter are more likely to go to the city center only when needed, while reserving their strolling pleasures for the streets and piazzas of their own neighborhoods. The difference in geographic choices is predominantly based on convenience, but the perception that downtown people are "stuck up" (se la tirano), as a teenager from the peripheral Rivarolo neighborhood put it, may also play a role here. Much of this discomfort is because each of the sites of the Genoese passeggio (urban stroll) has its own prescriptions for practice: discursive cultural codes that are incessantly negotiated through a two-way traffic between the meanings inscribed into the physical environment and the way passersby experience and engage them (Richardson 1982). A lot of these codes have to do with the public performance of what Pitkin (1993) and Del Negro (2004) identified as the social requirement of performing bella figura (i.e., making a positive impression) by showcasing one's class-specific distinction (Bourdieu 1984) and "good taste" (buon gusto) through the choice of clothes and behavior that are deemed appropriate for the place and the occasion. For example, a moderate degree of informality is not uncommon among women running quick errands close to their homes. In middleclass neighborhoods, sweat suits and sneakers are acceptable if one is jogging or stealing out after dusk to put out the trash. However, such attire becomes inadequate for relatively more prolonged exposures to one's neighbors' gazes (and possibly gossip), such as on a trip to a local store. Going downtown requires even more attention to one's appearance. As my interviewees suggested, whether you are heading for your 
office or are planning to do "laps," you need to make sure that your make-up and clothes are within the limits of both decency and current (or at least recent) fashion. If you are an adult, you should expect "improper" (i.e., old, dirty, or gaudy) clothes to earn you sardonic glances, winks, and giggles. Individuals behaving loudly or "inappropriately" in public places are frequently met with an explicitly censorial gesture. Following a well-worn script, the passerby who detects a breach of civility for example, by a group of unruly teenagers - may stop and turn not just his head but also his whole body towards the maleducati (ill-behaved ones). For a few seconds, the censor will furrow his brows to look conspicuously at the offenders-an indexical move that will cause others to identify the culprits by following his gaze. Then, after shaking his head and perhaps muttering a few words of reproach, he will be back on his way. The power of the censor's performance is that of temporarily embodying society at large: la gente (the people), understood as the imaginary, faceless, anonymous yet powerful public of neighbors, acquaintances, and strangers, who are imagined as watching one at all times, and whose opinion can be feared or challenged but always bears a normative value.

\section{Women's Spatial Belonging}

The consistent failure to produce a bella figura may result in the gente issuing sanctions ranging from sneers to ridicule, and from open reproach to a damning social isolation. Yet, the production of a proper urban persona is not only based on the competent display of membership in a social class. In what follows I argue that, in Italian cities, gender constructions also play a paramount role in shaping the experience of publicness. Anne Marie Fortier (1999) defined "belonging" as the blending of a performatively reiterated social identity with the claim to the ownership of a place. By drawing on this notion, I suggest that, in Genoa, the sense of belonging generated through both performance and performativity ${ }^{10}$ of class and gender further complicates the claims of spatial belonging through which men and women struggle over their physical and symbolic places in the public realm.

There is little question that Italian streets are a male domain. In Genoa, like in any other Italian city, the built environment and the discursive symbolic economy (Zukin 1995) of billboards, signs, and graffiti conspire in masculinizing urban space. In the bourgeois neighborhoods that surround Genoa's downtown, for example, "public" urinals for men only provide their users with, at best, a symbolic privacy, leaving it to respectable female passersby to avert their gaze to comply with the rules of modesty (see Figure 1). Further semantic layers are injected into one's urban experience by ubiquitous billboards that seek to promote the sales of drinks, cars, and cellular phones by displaying female body parts. This scenario of a rigorously masculine public realm is sealed by the grassroots spontaneity of graffiti disseminating in-yourface claims about politics, soccer, and sex. Polemical though they might be, the messages sprayed on the stuccos, marbles, and frescoes of Genoa's downtown façades invariably posit a hypermasculine and mandatorily heterosexual subject for statements such as "I want pussy not war" (Voglio la fica non la guerra), or "The supporters of Genoa [soccer team] are all fags" (Genoani froci). (See Figure 2.) 


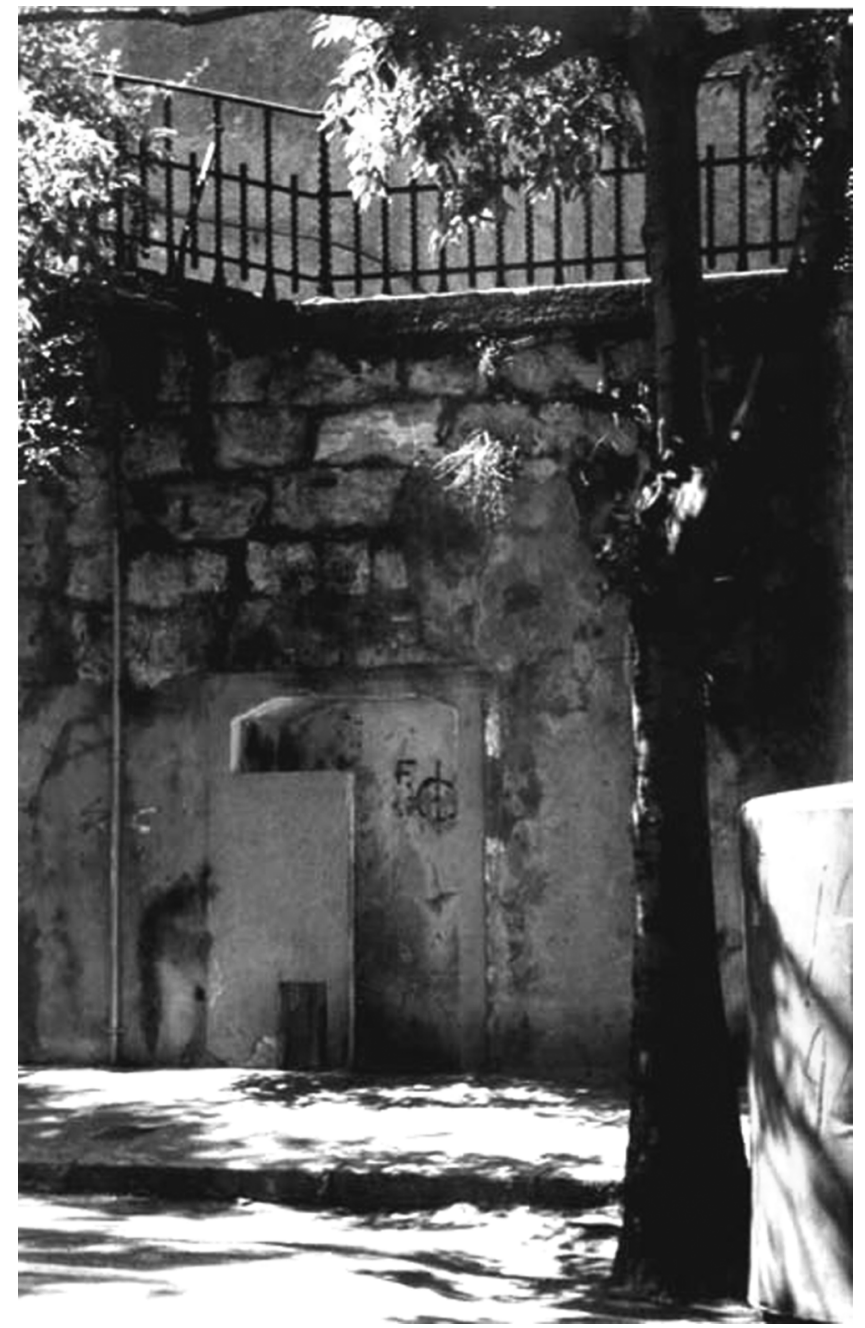

Figure 1. Urinal in the Castelletto neighborhood.

As they move through a cityscape that keeps being reproduced as their own domain, Genoese men are generally allowed a freer behavior than are women. For example, establishing turfs, talking loud, cursing and yelling profanities, spitting, revving up the engine of one's scooter or car, glaring at women, and making loud (and lewd) remarks about them are all common performative markers of public masculinity. If not precisely desirable from a middle-class perspective, such behaviors are nonetheless somewhat condoned; indeed, they are almost expected of teenagers and working-class men whose "poetics of manhood" (Herzfeld 1985) asserts itself against the grain of bourgeois canons. This rowdiness may also provide socially disenfranchised men with a venue for performatively claiming a patriarchal masculinity that is undermined by high unemployment rates (Del Negro 2004; Willis 2001). Any of the above-mentioned practices, however, would be strongly frowned upon if exhibited 


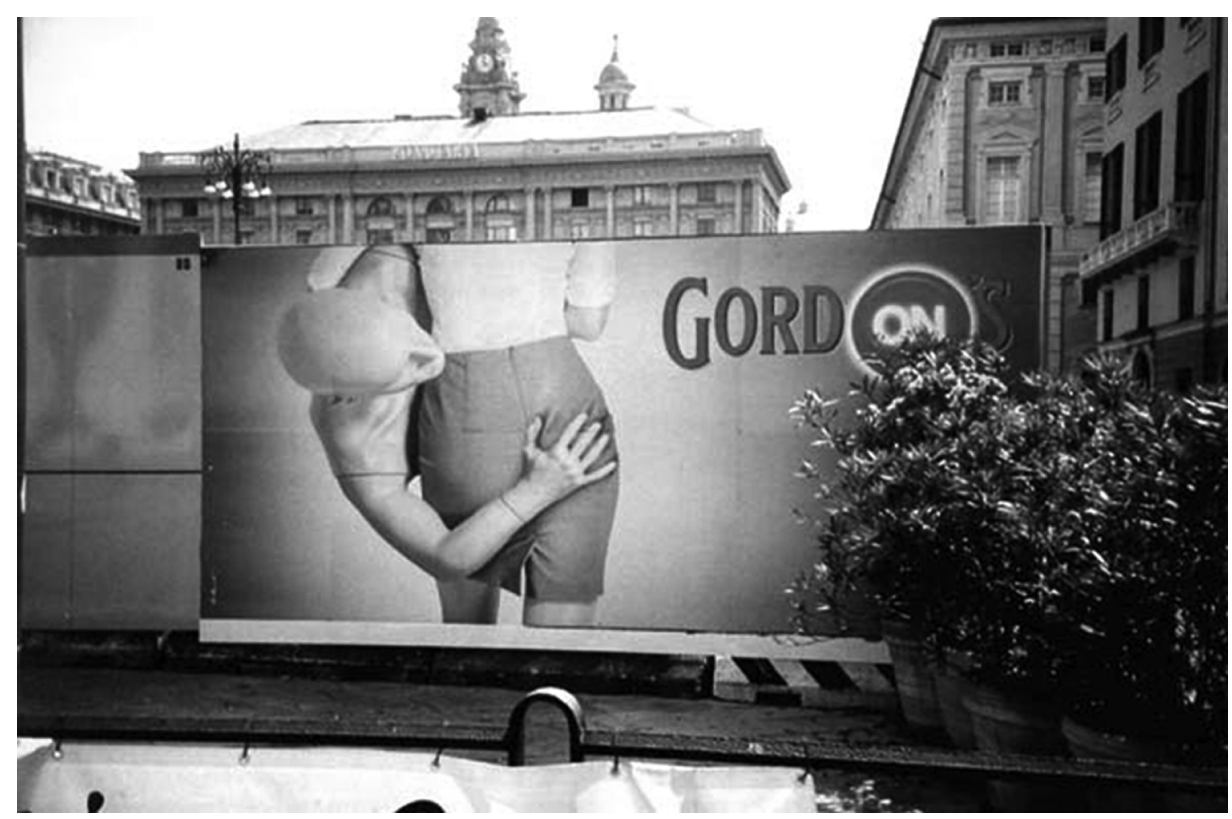

Figure 2 A billboard in Genoa's main piazza.

by women. Though they may encounter moderate sanctions in doing so, men can afford to issue a clear and loud claim to their place in the public realm. Proper ladies, however, hardly if ever do.

Middle-class women's belonging in the public realm is largely limited by the unwritten rules of respectability. While walking in the streets of Genoa, you rarely see groups of middle-class women killing time on a street corner or dangling their feet from a brick wall. If tired, women may occasionally sit on a bench for a few minutes or stop on the sidewalk for a brief chat with an acquaintance, but they will mostly do so in passing. If they enjoy sitting at a bar or coffee shop, they will tacitly refrain from patronizing the same establishment on a regular basis: women who hang out in a bar without a fixed male chaperon may earn the reputation of being "loose" (leggere). In general, it is safe to say that middle-class Genoese women rarely claim a place and fill it up with a permanent presence the way groups of men often do. Of course, middleclass women are ubiquitous in the city. However, they usually pass by and flow through; they are never there to stay - and thus to claim their "belonging" in the public realmin the way that men are. When women are seen lingering by themselves on a street or a piazza, there is, there must be, something wrong with them. They must be deviants of some sort-prostitutes, for example.

Also known as donne di strada or donne da marciapiede (literally, "street" or "sidewalk" women), prostitutes do have their own have turfs, street corners and neighborhoods that acquire a bad reputation because of their presence. ${ }^{11}$ Even though they usually materialize in the dim light of the night, prostitutes are trapped by the very visibility that bourgeois morality regards as their offense to the rules of gender and place. In the discourse and practice of the Genoese middle class, the prostitute's 
ownership of place is represented as bizarre: a titillating freak spectacle marked by these women's "inappropriate" behavior and clothes. Hence the institution of the puttangiro (prostitute viewing tour) perpetuated by all-male as well as coed youth groups: when it is late at night and all bars and clubs are closed, the only form of entertainment left in the city seems to be that of driving around the city to observe, and deride, prostitutes at work. ${ }^{12}$

Prostitutes are not the only women whose "improper" use of public space is branded-even as it brands them-as abnormal. Female beggars and panhandlers are seen in this way as well, and so are women belonging to marginal ethnic groups. ${ }^{13}$ Once I observed a group of teenage girls sitting on a stoop near a bus stop in Via Venti Settembre. They were chatting and laughing with each other, paying little attention to their surroundings; however, others paid a lot of attention to them. The people waiting for their bus seemed to be looking at the girls with a worried expression. Suddenly the owner of a nearby store catapulted herself out of her business and yelled: "What are you doing here? Go away! I am telling you, I am calling the police!" The girls did not seem surprised by this reaction. Laughing derisively, they stood up and quietly blended into the crowd at the bus stop. What on earth was going on? To me, these young women looked just like any other teenagers. When I voiced my astonishment, my friend laughed and said, "You spent too much time abroad and lost your [social] eye. Those girls were gypsies. Didn't you see their demeanor? Do you think normal girls would be sitting in the street like that?"

Respectable women cannot claim a permanent place of their own in the urban sphere. However, they may connect themselves to a place through men. In Genoa, groups of young people (compagnie) traditionally congregate in specific places-a street corner, a square, or a bar that becomes their turf. Being in that place means belonging in the group, and vice versa. Strangers who enter such places for brief periods will be ignored; if their intrusion persists, however, a confrontation may occur. Belonging to the group means successfully adopting a classed persona, and these groups are usually identified by their turf. The youth from Albaro, an upper-class neighborhood, are called albarini and are generally recognizable through their designer clothes and expensive cars. Their rivals, the young men and women from the middle- to upper-class Castelletto area, are known as castellettini. The castellettini dismiss the albarini as shallow and snobbish, and, as they pay relatively less attention to their appearances, they pride themselves on being more "down to earth" (alla mano). ${ }^{14}$ This claim is vehemently rebuffed by the young people from the workingclass neighborhoods at the periphery of the city, who are painfully aware of being branded as truzzi or cafuzzi (neologisms for cafoni, "boors") by albarini and castellettini alike. Regardless of class and neighborhood affiliation, however, most groups of young people around the city are predominantly composed of male friends who hang out together after school or in the evening and occasionally bring in their girlfriends. Girls are generally marginal: many of them join the group when they date one of its male members, but their association with the compagnia ends as soon as their romance is over. Once this happens, the girls usually lose their membership in the group, along with their right to the group's turf - an event that is even more distressing in that the process of earning this privilege is relatively long and pains- 
taking for them, especially when they are trying to cross class boundaries. This is how an eighteen-year-old described her position in one such group:

\begin{abstract}
I dated a guy for two years and a half, and he took me to his group [compagnia].... When we were with the group, he spent all his time with the other guys, and I had to stay with girls I had never seen before. They were also dating the guys of the group. ... There are few girls in a group. They are all from outside; when they break up with their boyfriend, the guy brings in a new girl and the old one disappears.... Once I dated a guy from Albaro who was in a group from his neighborhood, and I felt uncomfortable with those people. The girls kept to themselves, they stared at me and wouldn't talk to me. The guys told my boyfriend, "what a pretty girl you got yourself," but they wouldn't talk to me directly. I spent the entire evening on my own.
\end{abstract}

As another high school student put it: "It takes a girl a long time to become integrated in a group, longer than a boy. In the beginning, the girls won't talk to you and the guys won't, either. It takes at least three months to get accepted, but if you break up with your boyfriend, you are out." If girls can earn only limited access to the boys' turf, they can hardly establish a public place of their own. Two girls told me how they once decided that they would have a turf of their own. If all the guys they knew had one, why couldn't they? They selected the most panoramic corner of their neighborhood (one that had a stone wall on top of which they could easily sit) and appointed it as "their place." This is where they met for a while, and where they would entertain their own friends and dates. Yet most of their friends (both male and female) found it odd that girls would have a turf: it simply was not done. Soon the girls grew tired of the lewd remarks hurled at them by men who walked and drove by. Their turf project failed. As they had found out, a respectable woman might have a room of her own, but not a street corner. Good girls cannot carve themselves a place in public. They can only be guests, if they know how to behave and if they are aware of the price they might have to pay: the leers and sexual innuendoes that question their "belonging" in the urban sphere.

\title{
Public Harassment
}

Public harassment (Gardner 1995) accompanies the everyday life of many Italian women well into their adulthood. The catcalls, whistles, and even the occasional fondling and grabbing that litter almost every woman's experience of the Italian street are all too often romanticized in the U.S. media-especially fashion magazines and movies - as a quaint and somewhat complimentary aspect of Mediterranean exuberance. Yet there is little that is romantic about a behavior that not only is downright abusive but is also meant to undermine women's place in the public realm (Domosh and Seager 2001; Gardner 1995).

Violence against women in the public sphere is often a backlash against the relative improvement of their public status (Walby 1990). This violence does not pursue a forthright exclusion, but rather a surveillance and policing mechanism that perpetuates women's subalternity. This seems to be the case in Italy, where the struggles of first- and second-wave feminists attained remarkable results that peaked with fam- 
ily law reforms, the introduction of the right to divorce, and the legalization of abortion in the 1970s (Bono and Kemp 1991). Since then, more women have entered the workforce (even if, as of 2002, 52.7 percent of them were unemployed; see CENSIS 2003:233), and a scanty few, far fewer than in any other European country, have even made it to the upper-middle echelons of the political system. ${ }^{15}$ Throughout the $1980 \mathrm{~s}$ and 1990s, however, women's struggles and achievements have at best stalled, and at worst they have been quietly eroded or forthrightly challenged by the incessant action of the Catholic Church allied with conservative and moderate parties, as well as the relative indifference of the male-dominated left. ${ }^{16}$ Yet, the perspective of many Italian women on their condition could be only described as postfeminist. Since the conservative turn of the 1980s, the hegemonic perception has been that women have achieved full parity, thus making feminist struggles redundant (Valentini 1997). ${ }^{17}$ Hence, the word femminista has taken on a negative connotation: one that conjures the ghosts of bra-burning, man-bashing fanaticism. Feminism, to most Italian women and men, has become the female equivalent of maschilismo (masculinism), a philosophy of prevarication grounded in gender supremacy.

It would be inaccurate to claim that Italian women have no consciousness of the abuses and injustices that they suffer on a day-to-day basis; however, this awareness often remains anecdotal. As a result, most of the scattered stories of exploitation and violence that women tell each other fail to coalesce into a conscious, collective narrative of gender oppression and inequality. The media are complicit with this silence. For example, over the last several years, both conservative and liberal media have consistently failed to read a pattern of gendered violence in the appalling escalation of the number of women murdered by their husbands, boyfriends, and male acquaintances. ${ }^{18}$ In July 2003, after yet another uxoricide committed in Genoa by a Carabinieri ${ }^{19}$ officer who slaughtered his wife and two children, the news media monolithically quoted data generated by ISTAT, the national statistics bureau, to inform the public that more victims of so-called family murders were men, rather than women. This gender ratio was obtained by classifying as "family murders" the killings of neighbors and colleagues. ${ }^{20}$ When given the opportunity to comment publicly on the homicides, psychiatric experts of both local and national renown also took great pains to deny any gender politics by imputing the increase in women's murders to an illdefined "depression" epidemic. ${ }^{21}$

If such brutal violence against women can be successfully masqueraded and denied in the Italian public sphere, it is hardly surprising, then, that most stories of public harassment that Italian women suffer at the hands of men usually disappear in the limbo of the untold-because they are perceived as irrelevan $\mathrm{t}^{22}$ or even normal, but also because they are viewed as too embarrassing and shameful to be told. Public harassment is a forthright form of violence that is meant to make sure that women retain an uneasy, marginal position in the public realm (Gardner 1995). Drawing on Walby's argument (1990:143), I suggest that, while there are only a small number of men who actively partake in the public harassment of women, their individual acts are part of a larger a structure of violence that is supported by the quiet compliance of most Italians, including those women who suffer from it in silence. This silence also made it difficult for me to research, and write about, public harassment. 
Whenever I asked if they had ever been publicly harassed, most of my interviewees would at first hide behind a variety of vague statements: "Yes, it might have happened, but I don't remember." "Yes, but I don't pay attention to these things." "Yes it happened, but it doesn't matter now." Only later would many of these women open up to tell me painful stories of humiliation and abuse: situations that had often led them to question themselves and even to fear going out on their own. Yet, at first I could not understand their silence. Why were so many of my subjects, I kept wondering, initially unwilling to share their stories with me?

While attempting to elicit stories of harassment from my recalcitrant subjects, I witnessed a raucous incident of public molestation. In June 2002, I observed a group of about ten teenage boys who, escorted by a priest, were sunbathing at a local beach. For much of the morning, the boys had been able to generate surprisingly little conversation among one another and were visibly bored. Things changed when three women in their early twenties reached the tiny beach and laid their towels out a few yards away from the boys. Finally, the latter found a topic to discuss - the three women's breasts! First, the boys exchanged their remarks with each other and even with the priest. Since the priest feigned indifference to the boys' behavior, the latter grew bolder. Their comments became not only lewder but also louder: loud enough to be heard by the three women as well as anyone else on the beach. Gardner (1995:102) described public harassment as a "theatrical metaphor": rather than being agentive players in this public theater, harassed women are invariably recruited against their will by men who set the rules, the time, the stage, and the audience for their gender drama. ${ }^{23}$ The boys on the beach were crafting and performing a script of public manhood for the eyes of each other, their victims, and everybody else on the crowded beach. At the same time, they were also singling out and resignifying the women's presence in a public place as performances of an implicitly "out-of-place" sexual availability: rather than being agents in the public definition of a social space, the three women were being situated in it as passive objects of male gaze and action (Young 1990). The priest did not intervene to stop the boys, nor did any of the other adult men and women who witnessed the boys' behavior. Most importantly, the three women did not seem to react, even as the harassment continued for several hours. Why?

According to Louis Althusser, the act of hailing someone in everyday life has the effect of recruiting him or her as a subject, just like in the case of a police officer exclaiming, "Hey, you there!": "Assuming that the theoretical scene I have imagined takes place in the street, the hailed individual will turn round. By this mere one-hundred-and-eighty-degree physical conversion, he [sic] becomes a subject. Why? Because he has recognized that the hail was 'really' addressed to him, and that 'it was really him who was hailed' (and not someone else)" (1999:321). In the beach scene I witnessed, the boys' remarks publicly interpellated the women as collections of consumable body parts. The women feigned a painfully stiff indifference: one that was only too familiar to anybody who, at one time or another, has been in their very uncomfortable shoes. ${ }^{24}$ This indifference, I suggest, was an attempt to deflect the interpellation, thus rejecting the subject position the boys were creating for them, as if it had not been "really them" that the young men were publicly humiliating. 
Similarly, by initially declining to narrate their experience to me, my interviewees were refusing to reproduce their harassers' interpellation, as well as the performative triangulation between themselves, their aggressors, and me as their silent public - a situation whereby they had been unwillingly recruited as players in an uncomfortably public drama. As several young women pointed out, public harassment is even more hurtful when it is witnessed by others: the gente who, in the local social imaginary, constitute the arbiters of gendered and classed propriety, and in whose eyes they felt they had been demeaned. This is how one eighteen-year-old girl put it:

When I am in the street and a man approaches me, it really bothers me. The best thing to do when there are [other] people around is to just ignore him. If you are alone, you can go ahead and tell him that what he is doing is wrong. However, if there are people around, you do not want to have that kind of attention, and it's better for you to keep quiet... . The other day a friend of mine threw a tantrum when a man groped her.... I know she was right, but I still felt very embarrassed.

Needless to say, if the indifference feigned by the victims of street abuse signals their refusal to take up the subject position created for them by their harassers, rushing to acclaim the strategy of deflecting street abuse as purely resistive would be premature. In fact, even though the victim's obstinate silence is the only socially acceptable way of handling public harassment, this behavior does little to deter the abuse that is directed at women on a daily basis. What it does, instead, is to contribute to a complex, and often contested, web of representations about who belongs where, and why.

\section{Is Female to Male as Culture is to Nature?}

In the 1970s, anthropological analyses of public morality in the Mediterranean region revolved around the "honor/shame complex" (Peristiany 1974; Schneider 1971) and sought to demonstrate that, as the embodiment of their family's honor, women's virginity and sexuality were actively policed by their male kin. ${ }^{25}$ By casting an allochronic gaze on their "backward" objects (Fabian 1983), such approaches consistently disavowed local modernities (Del Negro 2004:68). Not surprisingly, in the Genoa of the early 2000s, any mention of the word "honor" would elicit a barrage of jokes pitting North Italian "modernity" against stereotypical "Sicilian backwardness." Indeed, female sexuality is hardly unproblematic in Genoese society, and yet many middle-class parents are more likely to discuss birth control methods with their daughters than to encourage a chastity that they often see as unrealistic. In this section I argue that, rather than being the prisoners of an honor web spun by their male kin, Genoese women are in fact managers of their families' respectability. This role, I suggest, has much to do with local constructions of gendered responsibilities and "nature" that are performed in the backstage privacy of the home as well as in public urban arenas.

In Italian cities, towns, and villages, groups of men can often be seen occupying public space, for example by sitting or standing in front of a bar or coffee shop, talking politics and soccer, and making remarks about the women who walk by. Upon 
spotting such a circle, women often take detours, or they brave the traffic by stepping off the sidewalk to avoid walking in front of or (even worse!) through the group of men who linger and watch. There was such a circle of men botanizing the asphalt in the Genoese neighborhood where I grew up. ${ }^{26}$ Day in and day out, the men sat in front of a small coffee shop and interrupted their conversations each time a woman walked by. I still remember those dreadful silences that lasted a handful of seconds: the interminable time you needed to take those five or six steps that plunged you into the space claimed by the men and took you out of it again. One day, a girlfriend of mine confronted the men. "Why do you keep staring at me? Don't you have anything else to do? Shame on you. Go get a job!" she told them, as we other girls cheered her bravado. "She shouldn't have done that," sneered one of our neighbors, an older woman, when she found out. "You don't make a scene in the street. What will people say?" (Cosa dirá la gente?)

Even after being confronted by my girlfriend, the men did not budge. They continued to claim their street corner to stare at the women who passed by, while the women living in that part of the neighborhood took detours to keep the men's eyes off their bodies. At the same time, however, the rumors about the men spread like wildfire. Some of them were said to be drug addicts and dealers; others were alleged to be alcoholics, thieves, and burglars. Neighborhood residents swore that none of the men could hold a job and that several of them were living off their parents or, even worse, their wives. "Men hanging out at a bar all day long," neighborhood women, and even some men, would blurt out loud in passing. "Don't they have a

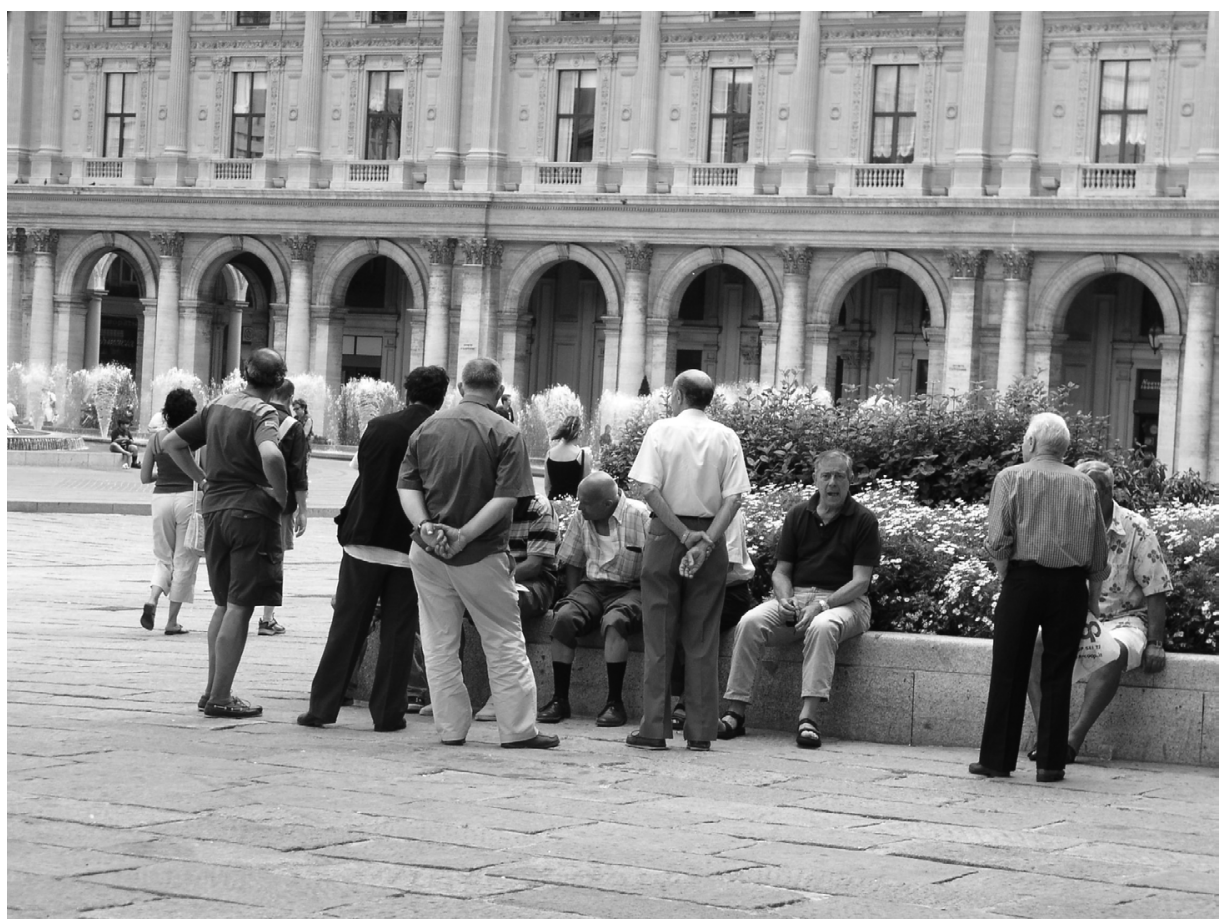

Figure 3. Men claiming space in downtown Genoa 
job?" After all, aren't men born to be responsible husbands and fathers, to work hard and provide for their families? Isn't idleness a vice, a moral shortcoming that diminishes a breadwinner's social worth?

As this example shows, women's resistance to the masculine appropriation of public space that is prevalent in Italian cities may emerge from within the dominant discourse on traditional gender roles and respectability. This practice obviously complicates Wilson's well-known argument (1973) about how respectability reproduces oppressive class hierarchies that are instead challenged by reputation as the cross-class display of masculine (and masculinist) prowess, virility, and bravado. Wilson's perspective indicts women for their role in preserving class inequality while it praises men for their healthy, if rowdy, subversion. In contrast, I seek to turn Wilson's argument upside down by drawing on Henrietta Moore's more nuanced treatment of the benefits and satisfactions that derive from situating oneself within institutional discourses and practices (1994:64-65). In fact, I suggest that many middle-class Genoese women may use respectability to challenge men's power and to claim their "belonging" in an otherwise oppressively masculinized public space-even as this strategy may legitimize class inequality and limit the modalities of women's own participation in the public realm. More specifically, in what follows I argue that middle-class Genoese women use the norms of propriety and bella figura to support their claims to a legitimate publicness—one that sets them a step "above" their uncouth male kin and abusive strangers alike. ${ }^{27}$

"If you respond [to public harassment] you stoop to their [the harassers'] level" ( $t$ i abbassi al loro livello), Genoese mothers often tell their daughters. In the context of social relations, the Italian verb abbassarsi is used to refer to the voluntary loss of a higher social position. Best translated as "to stoop," it literally means "to descend from a superior rank, dignity, or status." When Genoese women tell each other that, if you respond to public harassment, "you stoop to their level," not only do they represent society as a hierarchical structure with a "top" and a "bottom," with upper and lower layers, but they also find their place in it as "above" the men who question their belonging in the public realm. If, on one hand, this representation limits women's options to confront their aggressors, on the other hand it grants them a social superiority meant both to delegitimize humiliating interpellations and to help women to resist their symbolic ousting from public space. In addition, whereas among middle-class Genoese respectability is the domain of women, the boastful prowess Wilson describes as reputation is hardly acceptable of "proper" men. On the contrary, most adult, middle-class men are expected to accept gracefully their womenfolk's lead in taming their social inadequacies (their "nature") for the sake of a satisfactory class performance.

Yanagisako (2002) recently pointed out how, in northern Italian bourgeois and middle-class families, women are in charge of reproducing social standing through their cultural capital. Similarly, in Genoese middle- to upper-middle-class families, women are usually those who set the pace of their spouses' and children's public cultural life: by purchasing theater and opera tickets, by taking their husbands to museums and conferences, or by attempting to curb the latter's "tasteless" (read "working-class") passion for soccer. ${ }^{28}$ Beyond the responsibility for managing their 
family's cultural capital, women's duties also include the supervision of their symbolic capital-more specifically, the supervision of men's visual and performative personae, their looks, and their manners. In many Genoese families, mothers, wives, and sisters are in charge, not only of their own wardrobes, but also those of their male kin, whose clothes they purchase and monitor as part of the requirement of bella figura: that is, to produce a socially appropriate performance of their classed selves. The generally held belief is that most husbands, sons, and brothers are incapable of taking care of their appearance, and, if left to themselves, they will roam the city looking like barboni (hobos), thus embarrassing not only themselves but also their womenfolk. ${ }^{29}$ Men's alleged lack of finesse in the way they present themselves in public is something many women look down upon as a gendered form of social ineptitude: a "naturalness" that puts men at the margins of the world of properly cultured sociability.

The task of managing their own and their husbands' (or boyfriends', sons', single brothers', and widowed fathers') personae for the sake of a bella figura gives women a degree of power over their male kin - a control most men accept with little more than a playful resistance. However, this task also reproduces their domestic burden. The preparation for producing a bella figura obviously requires intensive backstage work (Del Negro 2004; Goffman 1959) that entails not only the job of correcting husbands' and sons' "naturally" bad manners but also a variety of activities such as shopping for apparel, washing, ironing, and mending their own and their male relatives' clothes. Like all other domestic chores, these are tasks that many Italian men are reluctant to take on (Couniham 2004; Neve 2002).

While not necessarily enjoying the drudgery generated by the upkeep of their male kin's wardrobe, women are often inclined to believe that men's aesthetic illiteracy (their disregard for the pleasures of fashion and proper grooming) severely limits the latter's options for pleasure. As Fabrizia, a forty-year-old white-collar employee, once put it: "Men's world is all black-and-white. We women instead live in a very colorful world." 30 While she insisted that being able to play creatively with their looks is women's privilege, Fabrizia pitied men for being constrained to monotony. "Wearing pants and shirts in dull colors all the time, day in and day out: can you imagine how dreary it is to be a man?" She then told me how she had purchased stylish red pants for her husband. At first, he did not want to wear them, but she finally made him do so- - a fact I confirmed when Fabrizia's husband came home donning his trendy red trousers.

Most of my subjects also argued that even educated middle-class men are usually less aware than their female counterparts of social norms or even the most basic rules of etiquette. In his analysis of reputation-making strategies in the Caribbean, Wilson (1973) had only praise for the creativity intrinsic to male rambunctiousness. In contrast, middle-class Genoese women are more likely to dismiss men's rowdiness as the product of an incomplete socialization. As one high school teacher put it, "Whenever you hear a group of people talk loud or use four-letter words in a public setting, that's bound to be men. Put three men together, and what you get is a pack of animals [branco]." One eighteen-year-old boy from a wealthy Castelletto family agreed: "If you hear someone burp loud in the street, that is always a man. For us, it's more 
natural. Women just won't do these things." Men's "naturalness" is hardly limited to the sphere of impression management (Goffman 1959). According to several of my subjects, the ultimate proof of men's incapability of controlling their instincts is their habit of molesting women - a custom that becomes almost justifiable through the consensus on men's "nature." For example, one eighteen-year-old told me how, only a few months earlier, she had been asked for help by a man sitting in a car. Once she opened the door of the vehicle, she realized that the man's lower body was bare. "I fled in shock," she said. However, when I asked her if she had reported the incident to the police, she shrugged her shoulders. "This is nothing unusual," she replied. "It is only stuff that men do because of their instincts." It is up to women, she suggested, to avoid trouble by distrusting strangers. Indeed, as Del Negro (2004:121) pointed out, Italian women are often expected to take it upon themselves to control sexual behavior. Men, instead, are more likely to be exonerated from this responsibility.

\section{Performing and Embodying Class and Gender}

The type of performance this article explores is what Judith Butler refers to as "performativity" - that is, the ongoing process of enacting gender through the very expressions that are said to be its results (1990:33). Unlike performance, which is framed by an explicitly aesthetic and theatrical setting, performativity takes place in everyday life. And yet, at a closer look, the boundaries between the two categories are fuzzy enough to allow interdiscursive incursions, especially when one sets out to disentangle issues of women's performative resistance to, and compliance with, patriarchal hegemonies.

As a display of communicative competence (Bauman [1977] 1984), an explicitly aesthetic performance may empower women to challenge existing gender roles (Sawin 2002). This is, for example, the case of the cowgirls at the Texan festival described by Beverly Stoeltje (1988). Drawing on both their riding competence and their role as representatives of their communities, the cowgirls achieved their goal of being evaluated on their actual skills, rather than on their appearances. ${ }^{31}$ Given its potential for subversion, women's transgressive aesthetic performance is often surrounded by a climate of social contempt. For example, as they dance lasciviously, sing about sex, and smoke in the company of men, the Moroccan shikhat dancers described by Kapchan (1994) flaunt an explicitly unrestrained public behavior, thus breaking many of the rules that govern female propriety in Moroccan society. Even as they enjoy an independence that is unknown to other women, shikhat have to deal with a climate of condemnation, stigma, and isolation that preempts their public disregard for social constraints (Kapchan 1994).

More importantly, women's aesthetic performance may also be empowering (or threatening, depending on the viewpoint) at a deeper level: one where the struggle over embodied subjectivities takes place. Drawing on the work of Mihaly Csikszentmihalyi (1974), Victor Turner suggested that a performer can achieve a blissful state of "flow" during which self-consciousness disappears: "a person 'in flow' finds himself [sic] in control of his [sic] actions and of the environment" ([1974] 1982:57; cited in Sawin 2002:37). More recently, Patricia Sawin (2002) observed that, as a 
"flowing" performance achieves a temporary suspension of social constraints on the performer's self, the latter may experience a degree of oblivion to the external gaze firmly cast on her persona. Additionally, a performer in such a flowing state may also evoke feelings (of sympathy and admiration, for example) capable of temporarily destabilizing dominant notions about gender (Sawin 2002).

Inevitably, achieving a pristine and unselfconscious state of flow is not an easy feat for women operating in patriarchal societies, where much care is taken to regulate the way women present themselves in their everyday lives (Goffman 1959; Sawin 2002). In what follows I argue that, as they perform their respectable selves, Genoese middle-class women seek to achieve a state of performative flow in which their respectability becomes naturalized beyond any possible doubt, thus supporting their right to be in public. Drawing on Turner's work, I suggest that the loss of self-consciousness that the state of flow brings about may also help women to temporarily block out the repressive gaze on their bodies and their behaviors, thus allowing them a degree of oblivious pleasure as they enact a stunning and very "natural" performance of what they are expected to do anyway.

As is invariably the case with doing gender, Genoese middle-class women's selfperformances as respectable ladies pivot on representation of nature. Just as they see men's nature as being uncouth, Genoese women often claim that their own nature combines what they describe as their nurturing instincts with an allegedly innate propensity for proper etiquette, good taste, and high culture. Their task of embodying and displaying class is not limited to managing their family members' bella figura, but it is, first and foremost, inscribed on their own selves through a painstaking work of social magic (Moi 1991) — a practice that, I argue, blends a degree of volition with a fiction of naturalness that essentializes class and gender identities by denying agency.

Just like gender, one's class identity is imagined as rooted in the body. "La classe non é acqua" (class is not water) is the refrain that punctuates the upbringing of many middle- and upper-class women. Almost like aristocracy, class is hardly perceived as based exclusively on income. On the contrary, it is understood as something that is more like blood: the thick and quintessential social fluid that nourishes one's inner and outer self. "If you are a real lady, you can wear any rag you bought at a street market and still look classy. Money can't buy that," many middle-class Genoese mothers tell their daughters. ${ }^{32}$ Not only can social distinction not be bought or sold, but it is also alleged to shine through everything a classy woman wears and does. A lady's posture, her demeanor, her walk, the pitch of her voice, her vocabulary, her table manners, and the way she sits and stands are among the performative choices that broadcast her social class (Del Negro 2004:131), and they are the product of the strict discipline she undergoes throughout her life. This intensive training has to start very early in life to inscribe a convincing naturalness in a woman's persona: a naturalness that eventually denies the very same learned quality of her classed and gendered identity, as well as her own performative agency. ${ }^{33}$

As Sawin (2002) observed, women in patriarchal societies are expected to carefully perform themselves in their daily life: their femininity, their propriety, their virtues and qualities. However, explicitly framing their performativity as a willful 
performance may result in a loss of status. Even though many Genoese women actively pursue the performance of bella figura as their claim to belonging in the public realm, several of them do not acknowledge their intentional involvement in this activity. In fact, they are expected to walk the fine line between consciously crafting the best possible performance and simultaneously denying their efforts as performers (Berger and Del Negro 2004:117). The consensus among my subjects was not only that it would be immodest for a woman to boast about the admiration she gets from strangers (both men and women), but also that only parvenus are explicitly concerned with the kind of (positive) impression they make when in public. Women may invest a considerable amount of time and effort in preparing to leave their homes and become an object of public scrutiny. And yet, even those subjects who declared that they invariably draw an admiring interest when in public claimed that they do not pay attention to it - on the contrary, they usually learn about it from their friends:

Emanuela: Do people [gente] look at you when you are in public?

MARIELLA: Yeah, I know they look at me when I go places. Not that I notice it myself, but [a friend] told me: "You know, wherever you go, people look at you." And I told her, "But I don't do anything to attract this attention, I am just being natural," and she told me, "I know that you are natural because I know you well, but people look at you nonetheless."

Mariella's behavior during our interview (which took place in a downtown coffee shop) seemingly confirmed her claims. Clad in an elegant designer outfit and matching ethnic jewelry, Mariella exhibited a self-assured demeanor and impeccable manners throughout our conversation. At the same time, not even once did she look at or acknowledge any of the other coffee shop patrons. Mariella was in a state of performative flow, completely absorbed in her perfect performance of classy femininity and seemingly oblivious to the other patrons in the coffee shop. When I asked her why she does not pay attention to others while in public, she replied "non sta bene" (it wouldn't be proper).

The only time when she made eye contact with a couple sitting next to us was when her eight-year-old niece gave out a loud shriek. Abruptly emerging from her flow, Mariella blurted: "Behave yourself! What will these people think, that you are an illbehaved young lady?" (Che cosa penseranno i signori, che sei una signorina maleducata?) She then turned to the couple to apologize to them. Evidently, admitting to the extent to which she depended on the outside gaze to validate her gendered and classed self-performances could have potentially undermined Mariella's flow and her selfconfident, "natural" poise, thus laying bare both her vulnerability and her anxieties vis-à-vis the public gaze on her persona.

In the central Italian village described by Del Negro (2004; see also Del Negro and Berger 2001), women's disinvoltura (poise) is understood as the ability to exhibit the right amount of self-assuredness, sexual propriety, and sociability when in a public setting. The women Del Negro observed, however, are also expected to "gracefully acknowledge the attention [their] performance prompts" as they stroll under everybody's eyes (2004:133). Living in an urban setting where the chances of running into 
an acquaintance are much thinner, my subjects volunteered instead a different notion of disinvoltura - one whereby openly acknowledging the external gaze cast on one's performance of class and gender would be inappropriate. As in Mariella's case, the strategy of avoiding eye contact with strangers is usually conceptualized as a basic rule of etiquette meant to protect anonymity and privacy, one's own as well as that of others. More importantly, the eagerness to scrutinize the reflection of one's propriety in the gaze of others could open a dangerous crack in a supposedly unselfconscious performative flow during which one is to impress one's publics instead of surrendering to their scrutiny. Certainly, most women I interviewed and observed were deeply concerned with what people think about them. Nevertheless, all of them also argued that they enjoy grooming and dressing up to go to public places, but they do so "only for themselves, not to be looked at," thus pretending to dead-end their performative and communicative activity at the border between the "natural" self they so carefully craft and the public gaze that evaluates their (hopefully flowing) performance.

The strategy of asserting oneself both through and against one's publics while denying one's agency and volition in the process points to the multiple-and simultaneous-levels of resistance and compliance women enact in their encounter with structures of class and gender in the public realm. For one, suggesting the naturalness of one's skills at generating bella figura confirms the notion that class is "in your blood"- that is, embodied and innate. Denying one's willful efforts at making an impression also signals a commitment to the rules of modesty and a lady's uneasy place in the public realm, a place that is marked by a fleeting passing through, rather than a claim to stable belonging. However, seeing oneself as capable of attracting an admired interest is a self-representation that points to a resistance to, and even a victory over, a public that is thus imagined as impressed by one's "flowing" spectacle of gendered propriety: the very same gente whose opinion is the benchmark of a woman's respectability and her place in society.

\section{Conclusion}

In this essay, I examined the discourse and practices associated with classed and gendered respectability in the streets of Genoa, and I argued that middle-class women's efforts to generate bella figura are in fact a strategy to assert their legitimate belonging in a highly masculinized-and explicitly sexist-public realm. Against the claim by Mosse (1985), Wilson (1973), and Abrahams (1983) that respectability is exclusively a static set of norms engendering repressive social relations, I suggested that women's performances of propriety entail both struggle and consent, and these performances allow women to resist their exclusion from the public domain even as they reproduce the restrictions that weaken their claim to it.

Just as men's traditional role as providers may simultaneously sanction their belonging in public and be used against them when they loaf at a street corner, women's responsibilities as caregivers may blend shades of empowerment and compliance. Genoese middle-class women in particular are in charge of managing their own and their family's cultural and symbolic capital for the sake of generating a bella figura, 
thus creating a public performance of propriety that reinforces their families' social standing. Cumbersome though it might be, this task also grants women a degree of control over their menfolk's personae-their looks as well as their behavior - through a discourse that represents men as incapable of transcending their uncouth "nature" without the lead of a woman. Additionally, a successful performance of bella figura supports a woman's right to be in public, though such a right is not without its ambiguities. In fact, a lady's "belonging" in the public domain has to be negotiated along a fine line that blends modesty with an accomplished, flowing display of education, good taste, and social graces. Even as many middle-class women undergo a lifelong discipline to create a persona that is adequate to their social standing, they are also required to conceptualize their performative skills as innate. As it essentializes women's gender and class, this requisite obscures women's agency in a game at which many of them excel: that of turning the gente as the feared arbiters of their respectability into a docile audience for their own successful self-performances.

\section{Notes}

1. For all its buoyancy, however, Italian street sociability has been the object of comparatively few ethnographic studies. Part of the reason for this neglect is the almost-exclusive concern with peasant life in the rural south of the country that, until relatively recently, has characterized much Italianist scholarship (Kertzer 1983).

2. Also tracing the passeggiata tradition back to the self-performances of sixteenth-century Italian aristocrats, Del Negro (2004) argued that it is only in the 1960s that other sectors of Italian society took to this practice. This is when, as the quick industrialization of the north of the country drove up percapita income and white-collar employment rates, the rising Italian middle classes could finally afford to publicly display and consume the accoutrements of their newly found modernity (Ginsborg 1990:237).

3. All interviews were conducted in Italian. The translations in this article are by the author.

4. The notion of the city as a theater for the performative negotiation of identity has long been a theme in urban studies and the social sciences (see, among others, Goffman 1959; Hannerz 1980; Lofland 1998; Richardson 1982; and Sennett 1977). On the urban sphere as a stage where the struggle over power and (in)equality is enacted through performative strategies, see Guano (2002); Hénaff and Strong (2001); Holston (1988); and Mitchell (2003).

5. The project involved not only participant-observation in Genoa's crowded streets, plazas, and beaches, but also thirty-five in-depth interviews with women ages eighteen to sixty-four. Some of my interviews spanned several encounters during which my subjects and I negotiated intense exchanges of experiences and thoughts, shared laughter and anger, and both agreed and argued over women's place in a city that has been ostensibly made by, and for, men. For the sake of protecting the privacy of my interviewees, pseudonyms are used throughout the article.

6. As Crick pointed out, the first question the ethnographer should ask of her- or himself is "why this research problem?" (1992:175). Del Negro (2004), for example, reported how her own scholarly interest in public identity performances in her parents' hometown was fueled by her own socialization in bella figura as an Italian Canadian. Similarly, Italian Australian Loretta Baldassar (1999) took the "road home" to her parents' birthplace in Veneto in order to explore the local discourse about a diaspora that involved her own family. In contrast, my intellectual concern with the Italian public realm is not based on the need to find my "road home." In fact, the questions I explore in this essay emerge from the multiple displacements and the permanent in-between-ness that characterize the life of a first-generation Italian immigrant to the U.S. - still out of place in a North American suburb, and yet no longer fully at home in the Italian street.

7. In 1965 , Genoa had 848,121 inhabitants. The decrease is largely due to a drastic drop in birth rates, 
only moderately compensated by the migration from the south of the country well into the 1970s and the onset of African, Asian, and Latin American immigration at the end of the same decade (Arvati and Carpa 2001). An additional factor in the demographic decline is the convulsive process of deindustrialization that took place in the 1980s and caused a high unemployment rate and a subsequent flight toward other cities.

8. Even though, since the 1980s, a moderate degree of suburbanization has taken place in Genoa, this exodus has been largely limited to those who had trouble sustaining an increasingly expensive urban lifestyle - that is, mostly the lower-middle-class and working-class families that moved to the villages of the entroterra (the hilly countryside surrounding the city) or, more rarely, to the Riviera.

9. This would most likely be an adult male, as a respectable woman would rarely seek a public confrontation.

10. Drawing on Bauman's work ([1977] 1984), Del Negro and Berger defined performance as a "mode of behavior in which the performer takes on responsibility for a display of competence" (2004:15). While performance is intentional, performativity as defined by Butler (1990) is the often-unreflexive practice of producing gendered identities.

11. In October 2002, the right-wing government led by Silvio Berlusconi sought to legalize again the existence of brothels, while approving the imposition of heavy fines on prostitutes lounging in the street. While presented to the public as an effort to protect prostitutes from slavery and the dangers of the street, this policy was actually meant to "cleanse" the streets and squares of Italian cities, thus restoring a complacent public morality.

12. Nobody, however, pays any attention to the prostitutes' customers, whose invisibility is protected by social practice and the law. When, in the mid-1990s, a few Italian municipalities ordered the police to take pictures of prostitutes' patrons in their cars and mail them to their home addresses, a public uproar ensued in the name of privacy, and the practice was discontinued.

13. Just as in many other port cities, prostitution has always been rampant in Genoa. However, ever since the onset of non-European immigration in the late 1970s, there have been recurrent moral panics about the increasing presence of Latin American, Albanian, and African prostitutes-women who are regarded as being at fault, not just for their profession, but also for their ethnicity.

14. On how neighborhoods provide symbolic sustenance for their residents' everyday lives, see Low (2000:244).

15. Consistent with the perception that women do not truly belong in the political sphere, authoritative Italian newspapers such as Corriere della Sera and Repubblica utilize the patronizing sobriquet "politica in rosa" (politics in pink) whenever discussing issues relative to women's participation in politics.

16. In the 1990s, the conservative pressure to return women to the domestic sphere of the family and to their "biological role" as mothers intensified along with the public concern over the alleged effects produced on Italian demographics by an increasing presence of non-European immigrants in the country and the declining fertility of white Italians (Krause 2001). This discourse found a vocal support even in certain academic spheres. For example, during the 2003 conference of the International Union of Anthropological and Ethnological Sciences held in Florence, the president of the conference, Italian physical anthropologist Brunetto Chiarelli, issued an alarming statement. For every white Italian child, immigrant African women had six black children; as a result, Chiarelli argued, homo europaeus is on the verge of a quick extinction, while the homo africanus population in Italy is bound to grow exponentially. As a solution, Brunelli hinted at the institution of "mandatory maternity" for white women, which he compared to compulsory military draft for men. Chiarelli's ideas gained national resonance as they were uncritically reported by most Italian newspapers (ANSA report, 07/09/2003).

17. In July 2003, the Equal Opportunity Commission of the Italian parliament was abolished by minister Stefania Prestigiacomo of the right-wing government led by Silvio Berlusconi. Prestigiacomo's decision went largely unnoticed.

18. On the increase of sexual and domestic violence against women in the Italy of the late twentieth century, see Maher 1996.

19. The carabinieri are a military corps with police functions.

20. It is only in September 2004 that the Italian media started disseminating a more accurate statisti- 
cal breakdown of the escalation in family murders (up almost 10 percent from the previous year), as well as in the gender ratio of both victims ( 68 percent of whom are women) and perpetrators ( 80 percent of whom are men). No qualitative analysis was offered to explain these statistics (Eures-Ansa 2005).

21. On February 14, 2006, a Veronese man hammered his wife and daughter to death. Before the rampage, the man had not exhibited any symptoms of depression. Since the rubric of "violence against women" is conspicuously absent from the Italian public sphere, the media glossed the case as a defeat for psychiatry by reasoning that nobody had been able to diagnose the depression in time to prevent the murder (Asnaghi 2006).

22. For example, on July 4, 2003, the leading Italian newspaper Repubblica published a sarcastic editorial by Elsa Vinci entitled “Mani a posto, non si fa” (Keep Your Hands Down: That's Not Done). The editorial argued that the supreme court of Italy was wasting time and effort on trivial issues, such as finding that groping women's buttocks in the workplace is a crime. This verdict had reversed a 2001 decision in which fondling a woman against her will had been deemed legal.

23. As Gardner explains, "[Public harassment is] the imposition of a theatrical metaphor in which the situationally disadvantaged individual is the avidly watched player on display and the advantaged person becomes the master of ceremonies, who is able to dictate the moment's entertainment" (1995:82).

24. In pointing to "ignoring, blocking, and repressing" strategies as common reactions to street abuse, Gardner describes how "women who receive public harassment sometimes visibly increase muscle tension, even start to flinch; they may adopt a fixed stare or direct their stare to any target but the man who has spoken. ... They may start to tremble or hear their heart pound, feel a sudden or atypical facial tic or muscle spasm, or note the bile rise in their throat" (1995:208-11).

25. The pun on Ortner's (1972) classic argument that "Female is to Male as Nature is to Culture" is intended.

26. The phrase "botanizing the asphalt" was coined by Walter Benjamin to describe poet Charles Baudelaire's practice of flânerie as the art of hanging out in the city while observing its spectacles (1983:36).

27. On the construction of bella figura as a predominantly feminine concern, see also Del Negro 2004.

28. This gendering of competences begins in school. While it is common for middle-class men to get a technical or scientific training that is meant to reinforce their role as providers by preparing them for a career, women are encouraged to opt for humanistic disciplines such as literature, art history, and foreign languages - a training that provides them with an appreciation of high culture that is often less accessible to middle-class men (Guano 2006).

29. On women's responsibility for their male kin's appearance and bella figura, see also Goddard 1991.

30. Inspired by Simone de Beauvoir's (1953) arguments about women's narcissism, some feminist writers have objected that women who concern themselves with their looks and personae have internalized the male scopic regime. Taking the hard line on a practice that is common to millions of women, Sandra Bartky, for example, dismissed the creativity of appearance work as the delusion of the compliant victim of patriarchy: "Painting the face is not like painting a picture. At best, it might be described as painting the same picture again and again with minor variations" (1990:71). However, this hasty dismissal fails to take into account not only women's own pleasure (Beausoleil 1994:46) but also the dynamics through which the performative production of their personae would actually contribute to legitimize women's presence in the public realm as competent subjects.

31. On how the performative roles that seek to reproduce patriarchal gender norms may result in a relative empowerment for women, see also Stoeltje's (1996) analysis of a beauty pageant at a Texas festival.

32. This is not to claim that Genoese middle-class women have no interest in acquiring expensive designer clothes and accessories. However, extravagant fashion shopping is remarkably less common in Genoa than it is in other Italian cities.

33. Adult women who are caught in an attempt to learn how to perform class (for example, by reading etiquette manuals) are usually derided as phony. 


\section{References Cited}

Abrahams, Roger. 1983. Men-of-Words in the West Indies: Performance and the Emergence of Creole Culture. Baltimore: Johns Hopkins University Press.

Abu-Lughod, Lila. 2002. Do Muslim Women Really Need Saving? Anthropological Reflections on Cultural Relativism and its Others. American Anthropologist 104(3):783-90.

Althusser, Louis. [1971] 1999. Ideology and Ideological State Apparatuses (Notes Towards an Investigation). In Visual Culture: The Reader, ed. Stuart Hall and Jessica Evans, pp. 317-26. London: Sage.

Arvati, Paolo. 1988. Oltre la Cittá Divisa. Gli Anni della Ristrutturazione a Genova. Genova: Sage.

Arvati, Paolo, and Sabrina Carpa. 2001. I mille volti di Genova: La cittá in numeri. In La cittá e i suoi tempi. Un'indagine a genova sugli stili di vita e le dimensioni temporali, ed. Antida Gazzola, pp. 54-86. Milano: FrancoAngeli.

Asnaghi, Laura. 2006. Nessuno si è accorto che soffriva è una sconfitta per la psichiatria. La Repubblica. February 14, 2006.

Baldassar, Loretta. 1999. The Road "Home." Meanjini 58(3):42-60.

Bartky, Sandra Lee. 1990. Femininity and Domination: Studies in the Phenomenology of Oppression. New York: Routledge.

Bauman, Richard. [1977] 1984. Verbal Art as Performance. Prospect Heights, Ill.: Waveland Press.

Beausoleil, Natalie. 1994. Makeup in Everyday Life: An Inquiry into the Practices of Urban American Women of Diverse Backgrounds. In Many Mirrors: Body Image and Social Relations, ed. Nicole Sault, pp. 33-57. New Brunswick, N.J.: Rutgers University Press.

Benjamin, Walter. 1983. Charles Baudeilaire: A Lyric Poet in the Era of High Capitalism. London: Verso.

- 1985. One Way Street and Other Writings. London: Verso.

Berger, Harris M., and Giovanna P. Del Negro. 2004. The Role of Reflexivity in the Aesthetics of Performance: Verbal Art, Public Display, and Popular Music. In Identity and Everyday Life: Essays in the Study of Folklore, Music, and Popular Culture, pp. 89-123. Middletown, Conn.: Wesleyan University Press.

Bono, Paola, and Sandra Kemp, eds. 1991. Italian Feminist Thought. Cambridge, Mass.: Basil Blackwell.

Bourdieu, Pierre. 1984. Distinction: A Social Critique of the Judgment of Taste. Cambridge, Mass.: Harvard University Press.

Butler, Judith. 1990. Gender Trouble: Feminism and the Subversion of Identity. New York: Routledge.

Centro Studi Investimenti Sociali (CENSIS). 2003. 36mo rapporto sulla situazione sociale del paese. Roma: Franco Angeli.

Coole, Diana. 2000. Cartographic Convulsions: Public and Private reconsidered. Political Theory 28(3):337-54.

Couniham, Carole M. 2004. Around the Tuscan Table: Food, Family, and Gender in Twentieth Century Florence. London: Routledge.

Crick, M. 1992. Ali and Me. In Anthropology and Autobiography, ed. Judith Okely, pp. 175-92. London: Routledge.

Csikszentmihalyi, Mihaly. 1974. Flow: Studies of Enjoyment. PHS Grant Report. Chicago: University of Chicago.

De Beauvoir, Simone. 1953. The Second Sex. New York: Knopf.

Del Negro, Giovanna P. 2004. The Passeggiata and Popular Culture in an Italian Town: Folklore and the Performance of Modernity. Montreal: McGill-Queen's University Press.

Del Negro, Giovanna P., and Harris M. Berger. 2001. Character Divination and Kinetic Sculpture in the Central Italian Passeggiata (Ritual Promenade): Interpretive Frameworks and Expressive Practices from a Body-Centered Perspective. Journal of American Folklore 114(451):5-19.

- 2004. New Directions in the Study of Everyday Life: Expressive Culture and the Interpretation of Practice. In Identity and Everyday Life: Essays in the Study of Folklore, Music, and Popular Culture, ed. Harris M. Berger and Giovanna P. Del Negro, pp. 3-22. Middletown, Conn.: Wesleyan University Press.

Domosh, Mona, and Joni Seager. 2001. Putting Women in Place: Feminist Geographers Make Sense of the World. New York: Guilford Press. 
Eures-Ansa. 2005. Rapporto Eures-Ansa sull'omicidio volontario in Italia. http://www.eures.it/ricerche_sv/ omicide2005htm.

Fabian, Johannes. 1983. Time and the Other: How Anthropology Makes its Object. New York: Columbia University Press.

Fortier, Anne Marie. 1999. Re-Membering Places and the Performances of Belonging(s). Theory, Culture, and Society 16(2):41-64.

Gal, Susan. 2002. A Semiotics of the Private/Public Distinction. Differences: A Journal of Feminist Cultural Studies 13(1):77-95.

Gardner, Carol B. 1995. Passing By: Gender and Public Harassment. Berkeley: University of California Press.

Ginsborg, Paul. 1990. A History of Contemporary Italy: Society and Politics 1943-1988. London: Penguin.

Goddard, Victoria. 1991. Honour and Shame: The Control of Women's Sexuality and Group Identity in Naples. In The Cultural Construction of Sexuality, ed. Patricia Caplan, pp. 166-92. London: Routledge.

Goffman, Erving. 1959. The Presentation of Self in Everyday Life. New York: Doubleday.

Guano, Emanuela. 2002. Ruining the President's Spectacle: Theatricality and Telepolitics in the Buenos Aires' Public Sphere. Journal of Visual Culture 1(3):303-23.

- 2006. Fair Ladies: The Place of Women Antique Dealers in a Postindustrial Italian City. Gender, Place and Culture: A Journal of Feminist Geography. 13(2):105-22.

Hannerz, Ulf. 1980. Exploring the City: Inquiries Toward an Urban Anthropology. New York: Columbia University Press.

Hénaff, Marcel, and Tracy B. Strong, eds. 2001. Public Space and Democracy. Minneapolis: The University of Minnesota Press.

Herzfeld, Michael. 1985. The Poetics of Manhood: Contest and Identity in a Cretan Mountain Village. Princeton, N.J.: Princeton University Press.

Holston, James. 1988. The Modernist City: An Anthropological Critique of Brasilia. Chicago: The University of Chicago Press.

Kapchan, Deborah. 1993. Moroccan Women’s Body Signs. In Bodylore, ed. Katharine Young, pp. 3-34. Knoxville: University of Tennessee Press.

— 1994. Moroccan Female Performers Defining the Social Body. Journal of American Folklore 107(423):82-107.

Kerber, Linda. 1988. Separate Spheres, Female Worlds, Woman's Place: The Rhetoric of Women's History. The Journal of American History 75(1):9-39.

Kertzer, David. 1983. Urban Research in Italy. In Urban Life in Mediterranean Europe: Anthropological Perspectives, ed. Michael Kenny and David Kertzer, pp. 53-75. Urbana: University of Illinois Press.

Krause, Elizabeth. 2001. "Empty Cradles" and the Quiet Revolution: Demographic Discourse and the Cultural Struggles of Gender, Race, and Class in Italy. Cultural Anthropology 16(4):576-611.

Lefebvre, Henri. 1996. Writings on Cities, trans. and ed. by Eleonore Kofman and Elizabeth Lebas. Cambridge: Basil Blackwell.

Lofland, Lyn. 1998. The Public Realm: Exploring the City's Quintessential Social Territory. New York: Aldine de Gruyter.

Low, Setha M. 2000. On the Plaza: The Politics of Public Space and Culture. Austin: The University of Texas Press.

Maher, Vanessa. 1996. Immigration and Social Identities. In Italian Cultural Studies: An Introduction, ed. David Forgacs and Robert Lumley, pp. 160-77. Oxford: Oxford University Press.

Mitchell, Don. 2003. The Right to the City: Social Justice and the Fight for Public Space. New York: The Guilford Press.

Moi, Toril. 1991. Appropriating Bourdieu: Feminist Theory and Pierre Bourdieu's Sociology of Culture. New Literary History 22:1017-49.

Moore, Henrietta. 1994. A Passion for Difference. Bloomington: Indiana University Press.

Mosse, George L. 1985. Nationalism and Sexuality: Middle-Class Morality and Sexual Norms in Modern Europe. Madison: University of Wisconsin Press. 
Neve, Elisabetta. 2002. Donne in difficoltà. In Cittadini invisibili: Rapporto 2002 su esclusione sociale e diritti di cittadinanza, ed. Caritas Italiana, pp. 97-164. Milano: Feltrinelli Editore.

Ortner, Sherry. 1972. Is Female to Male as Nature is to Culture? Feminist Studies 1(2):5-31.

Peristiany, J. G., ed. 1974. Honour and Shame: The Values of Mediterranean Society. Chicago: University of Chicago Press.

Pitkin, Donald. 1993. The Domestication of Public Space: Street as Room in Southern Europe. In The Cultural Meaning of Urban Space, ed. Robert Rotenberg and Gary McDonogh, pp. 95-102. Westport, Conn.: Bergin \& Garvey.

Richardson, Miles. 1982. Being in the Market Versus Being in the Plaza: Material Culture and the Construction of Social Reality in Spanish America. American Ethnologist 9(2):421-36.

Sawin, Patricia E. 2002. Performance at the Nexus of Gender, Power, and Desire: Reconsidering Bauman's Verbal Art from the Perspective of Gendered Subjectivity as Performance. Journal of American Folklore 115(455):28-61.

Schneider, Jane. 1971. Of Vigilance and Virgins: Honor, Shame, and Access to Resources in Mediterranean Societies. Ethnology 10(1):1-24.

Sennett, Richard. 1977. The Fall of Public Man. New York: Knopf.

Stoeltje, Beverly J. 1988. Gender Representation in Performance: The Cowgirl and the Hostess. Journal of Folklore Research 25(8):219-41.

- 1996. The Snake Charmer Queen. In Beauty Queens on the Global Stage: Gender, Power, Contests, ed. Colleen Ballerino Cohen, Richard Wilk, and Beverly J. Stoeltje, pp. 13-29. New York: Routledge.

Turner, Victor W. [1974] 1982. Liminal to Liminoid in Play, Flow, and Ritual. In From Ritual to Theatre, pp. 20-60. New York: Performing Arts Journal Publications.

Valentini, Chiara. 1997. Le donne fanno paura. Milano: Il Saggiatore.

Walby, Sylvia. 1990. Theorizing Patriarchy. Cambridge, Mass.: Basil Blackwell.

Willis, Paul. 2001. The Ethnographic Imagination. Malden, Mass.: Blackwell.

Wilson, Peter. 1973. Crab Antics: The Social Anthropology of English-Speaking Negro Societies of the Caribbean. New Haven, Conn.: Yale University Press.

Yanagisako, Sylvia Junko. 2002. Producing Culture and Capital: Family Firms in Italy. Princeton, N.J.: Princeton University Press.

Young, Iris. 1990. Throwing Like a Girl and Other Essays in Feminist Philosophy and Social Theory. Bloomington: Indiana University Press.

Zukin, Sharon. 1995. The Cultures of Cities. Cambridge, Mass.: Blackwell. 